Article

\title{
Groundwater Quality Changes in a Karst Aquifer of Northeastern Wisconsin, USA: Reduction of Brown Water Incidence and Bacterial Contamination Resulting from Implementation of Regional Task Force Recommendations
}

\author{
Kevin Erb ${ }^{1, *}$, Eric Ronk ${ }^{2}$, Vikram Koundinya ${ }^{3}$ and John Luczaj ${ }^{4}$ \\ 1 University of Wisconsin-Extension Environmental Resources Center, 1150 Bellevue St, Green Bay, \\ WI 54302, USA \\ 2 University of Wisconsin-Extension, 206 Court Street, Chilton WI 53014, USA; \\ E-Mail: eric.ronk@ces.uwex.edu
}

3 University of Wisconsin-Extension Environmental Resources Center, 445 Henry Mall, Madison, WI 53706, USA; E-Mail: vkoundinya@wisc.edu

4 Department of Natural \& Applied Sciences, University of Wisconsin-Green Bay, Green Bay, WI 54311, USA; E-Mail: luczajj@uwgb.edu

* Author to whom correspondence should be addressed; E-Mail: kaerb@wisc.edu; Tel.: +1-920-391-4652.

Academic Editor: Damien Giurco

Received: 16 April 2015 / Accepted: 19 August 2015 / Published: 27 August 2015

\begin{abstract}
In the Silurian Dolostone region of eastern Wisconsin, the combination of thin soils and waste application (animal manure, organic waste) has led to significant groundwater contamination, including Brown Water Incidents (BWIs-contamination resulting in a color or odor change in well water) and detections of pathogen indicator bacteria such as E. coli and others. In response, a Karst Task Force (KTF) was convened to identify risks and recommend solutions. This article looks at the impact eight years after the 2007 Karst Task Force report-both the actions taken by local resource managers and the changes to water quality. We present the first regional analysis of the 2007 Karst Task Force report and subsequent regulatory changes to determine if these regulations impacted the prevalence of wells contaminated with animal waste and the frequency of BWIs. While all of the counties in the KTF area promoted increased awareness, landowner/manager and waste applicator education alone did not result in a drop in BWIs or other water quality improvements. The two counties in the study that adopted winter manure spreading
\end{abstract}


restrictions on frozen or snow-covered ground showed statistically significant reductions in the instances of BWIs and other well water quality problems.

Keywords: Silurian aquifer; karst task force; Wisconsin; karst; animal waste; manure; well contamination; regulations

\section{Introduction}

Karst regions are widespread across the world, and approximately $20 \%-25 \%$ of the global population depends on groundwater resources obtained directly from karst aquifers [1]. Karst aquifers are particularly vulnerable to microbial pathogens and other introduced substances resulting from surface land use activities due to a lack of filtration in the aquifer and short subsurface residence times [2]. Microbial pathogens include bacteria, viruses, and protozoan parasites. Conduits, such as sinkholes and swallow holes, provide direct access points that connect water in the surface environment to the karst aquifer below, often bringing with it contaminants that would not normally enter the aquifer by diffuse recharge, such as phosphate, pesticides, and pathogens [2]. Regions of karst bedrock with little or no soil or unconsolidated sediment cover are especially vulnerable.

Impacts to karst aquifers from pathogens and nitrates have been reported in karst aquifers from many parts of the world (e.g., [2-6]), and contamination from multiple sources, including animal waste, are well documented in parts of Wisconsin and the Midwestern United States where a regional Paleozoic karst aquifer is present (e.g., [7-13]), In Wisconsin, contamination from pathogenic indicator bacteria is often associated with "brown water" incidents (BWIs), resulting in a color or odor change in well water. BWIs have occurred for decades throughout northeast Wisconsin, often in the spring during snowmelt after application of bovine (dairy) manure on agricultural fields. Between 2006 and mid-2014, sixty-four well replacements were subsidized throughout Wisconsin due to confirmed contamination by livestock manure [7]; three-quarters of those wells were located in areas rated as having a significant to extreme vulnerability to groundwater contamination related to karst-type landscape features (e.g., sinkholes, disappearing streams, surface carbonate rock outcrops, and fracture traces) [13].

Thin soils are a particular risk factor for microbial impact and nitrate contamination of karst aquifers (e.g., [13,14]), Risk for groundwater contamination in karst aquifers as a result of manure application is higher when manure is liquid $(<\sim 12 \%$ solids); surface applied outside the normal growing season to wet, frozen, or bare frozen soils; applied to a wet snowpack ready to melt, or immediately prior to significant rainfall [14]. Ronk and Erb [15] noted that in Wisconsin, a majority of animal waste surface water contaminations due to runoff occur in the late winter runoff period. In particular, land application of manure on frozen soils in the Midwestern United States has seen increased attention because of concerns of the negative effects on surface water and groundwater quality $[13,16]$.

This article focuses on a four-county region in northeastern Wisconsin, USA (Figure 1a). Luczaj [17] provides a more detailed description of the geology in the study area, but a basic description of the geology is included here as necessary context. Paleozoic age sedimentary rocks, including dolostone 
and shale, underlie the region and dip gently eastward toward the ancestral Michigan basin [17]. The landscape displays relatively moderate topography, except along the Niagara Escarpment, which locally has cliffs and steep slopes as high as $70 \mathrm{~m}$. The escarpment occurs along and near the western edge of the Silurian dolostone in the region (Figure 1b) where the underlying Maquoketa shale has been preferentially removed by erosion. Bedrock across the entire study area is overlain by Pleistocene glacial till, glaciofluvial sediments and lacustrine sediments that range in thickness from $<1 \mathrm{~m}$ to $>100 \mathrm{~m}$ in buried bedrock valleys. The portions of this four-county area that are most heavily impacted by nitrates, pathogens and pathogenic indicators, and BWIs are located east of the Niagara Escarpment, typically in areas where the Silurian bedrock is mantled with thin soils or Pleistocene sedimentary cover [7,9]. West of the Niagara Escarpment, bedrock consists of Ordovician age shale and dolostone (Figure 1b), with generally thicker amounts of unconsolidated sedimentary cover [17]. Karst features are not typically observed west of the Niagara Escarpment in the four-county region identified in the study.

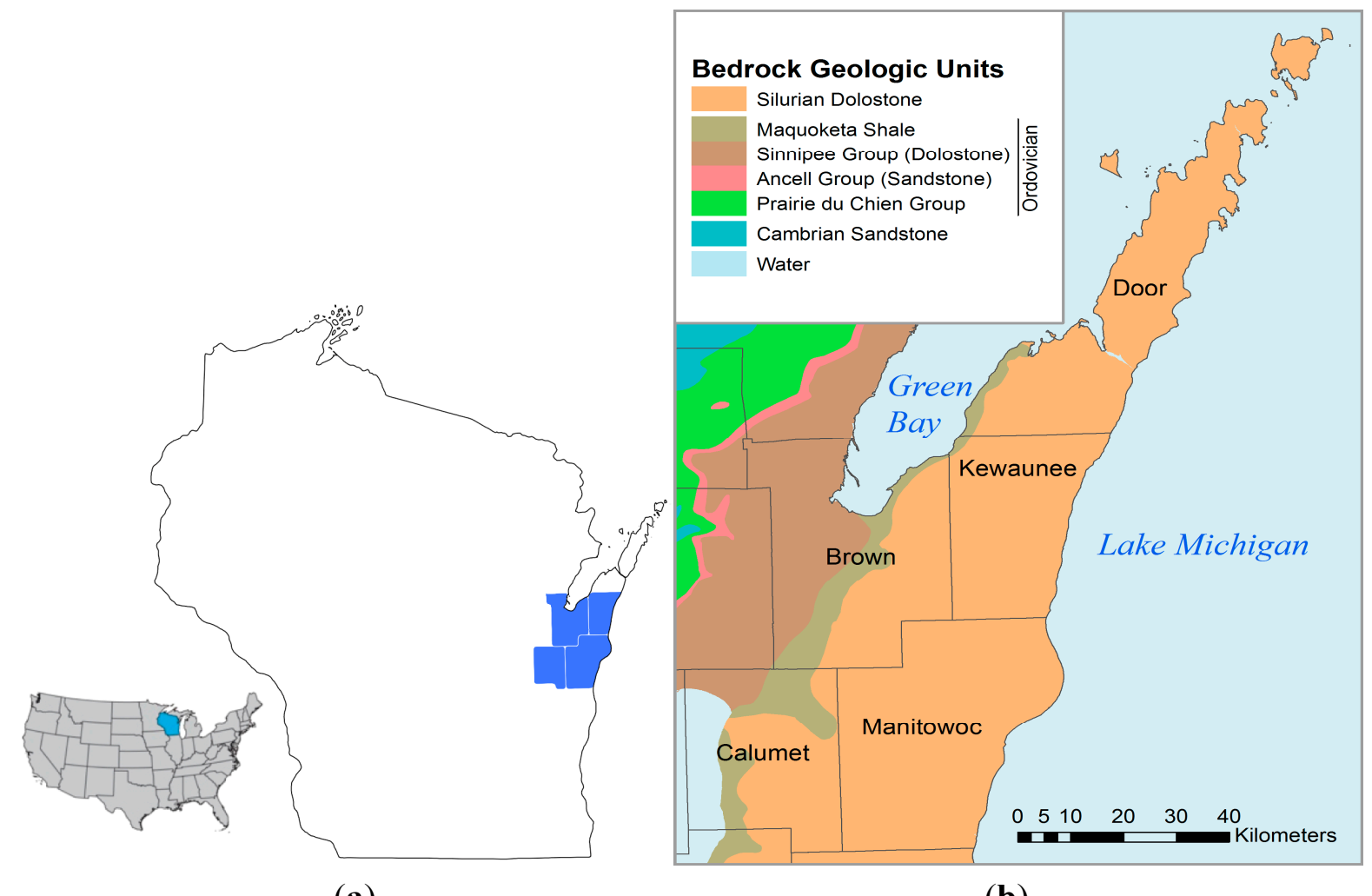

(a)

(b)

Figure 1. Maps showing the location of the four-county study area in Wisconsin, USA. (a) shows an inset map of the lower 48 contiguous United States along with an outline of the State of Wisconsin and counties (local units of government) for the study area highlighted; (b) is the bedrock geologic map showing geologic units for this portion of northeastern Wisconsin with names of counties in the region. Bedrock map after [18].

The Silurian bedrock east of the Niagara Escarpment displays significant karst development, albeit heavily modified by Pleistocene age glacial activity (Figure 1). Many karst features are exposed, such as sinkholes, solution-enlarged joints, and caves, which act as preferential recharge points to the aquifer. Most karst features are concealed beneath a variably thick mantle of sediment, but exposed areas of Silurian dolostone bedrock are common within about $15 \mathrm{~km}$ of the escarpment edge. Thin to 
moderate soils (defined for this region as $<15.25 \mathrm{~m}$ of soil over the bedrock) are also common in this area (Figure 2).

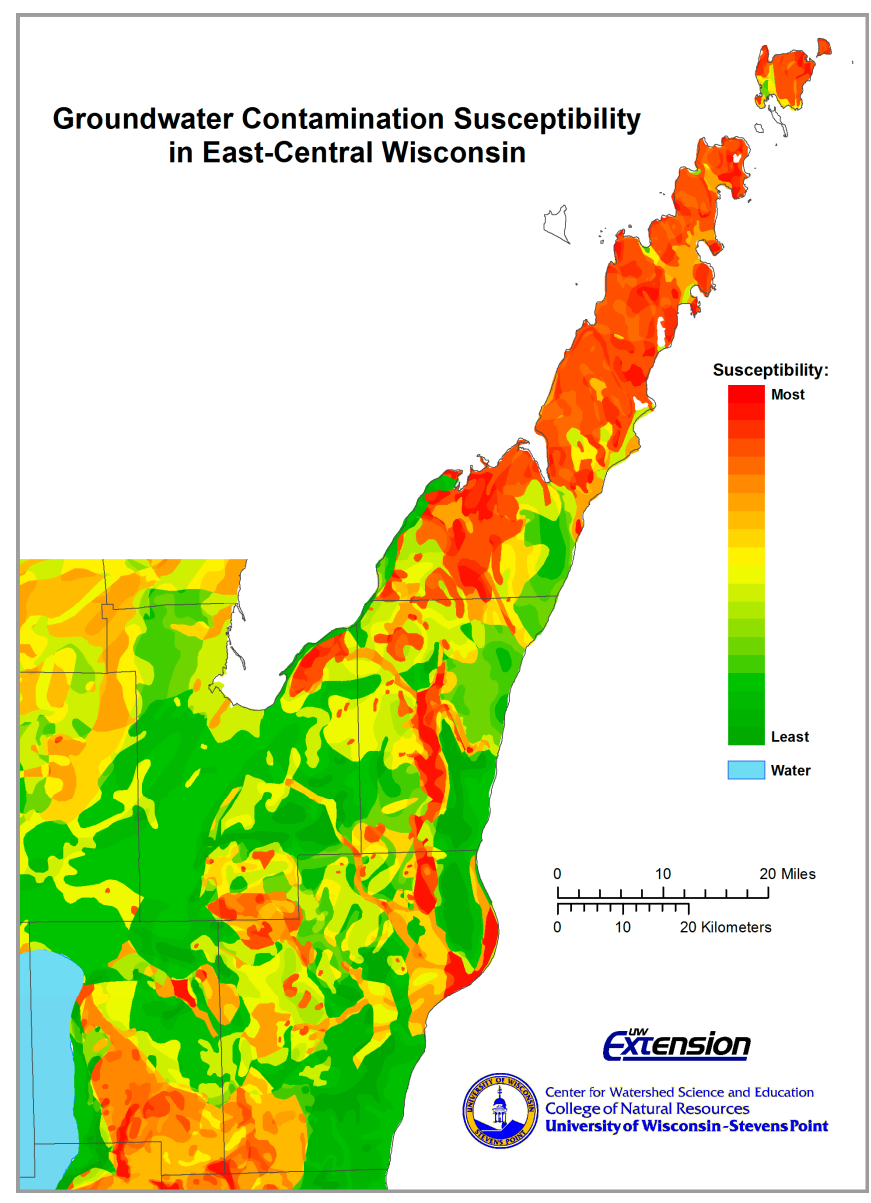

(a)

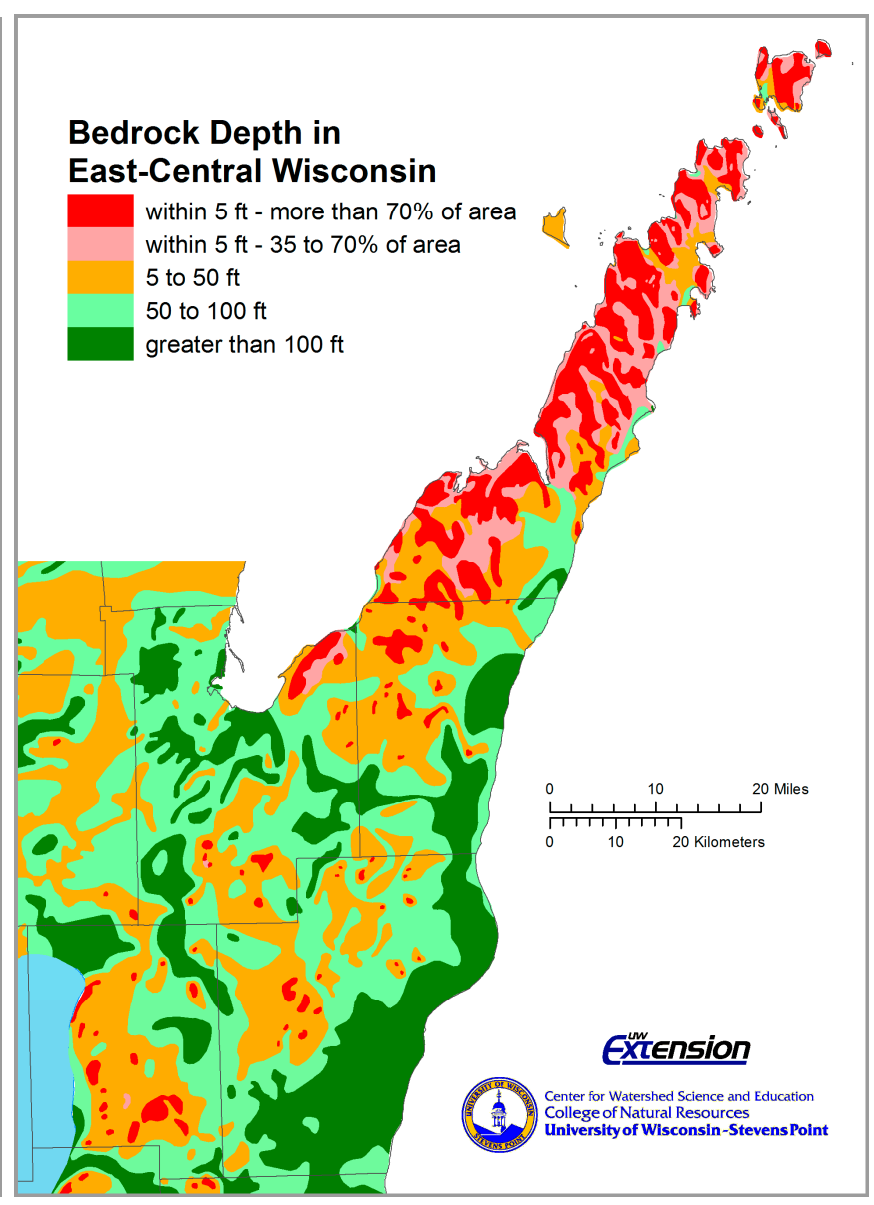

(b)

Figure 2. Maps showing soil depth (or unconsolidated sediment depth) over bedrock (a) and groundwater contamination susceptibility (b), based on soil type and depth to bedrock [13]. Original depth to bedrock map was constructed with categories of $<5$ feet $(1.5 \mathrm{~m}), 5$ to 50 feet ( 1.5 to $15 \mathrm{~m}), 50$ to 100 feet (15 to $30.5 \mathrm{~m})$, and $>100$ feet $(>30.5 \mathrm{~m})$.

Climatologically, the four-county study area (Figures 1 and 2) lies in a portion of the United States with a humid continental climate and cold winters. Mean annual precipitation (liquid equivalent) varies from about 75 to $84 \mathrm{~cm}$ (29.5 to 33 inches) [19], with about two-thirds of the precipitation falling during the growing season. Winter snowfall averages about 105 to $130 \mathrm{~cm}$ (41.3 to 51.4 inches) [19]. Average annual temperatures for the four-county study area range from about 6.6 to $7.4{ }^{\circ} \mathrm{C}\left(43.8^{\circ} \mathrm{F}\right.$ to $45.3^{\circ} \mathrm{F}$ ) [20]. The lowest mean monthly temperatures in the region occur during January, -9.4 to $-7.2^{\circ} \mathrm{C}$ $\left(15\right.$ to $19^{\circ} \mathrm{F}$ ), and the highest mean monthly temperatures occur during July, 20.0 to $21.7^{\circ} \mathrm{C}$ $\left(68-71^{\circ} \mathrm{F}\right)[20]$.

The presence or absence of seasonally frozen ground is an important climatological factor that can influence a number of groundwater quality indicators, including BWIs and variability in nitrates, chloride, alkalinity, and conductivity [9,14,16]. In the study area between 2006 and 2014, the average number of days of frozen ground per winter at Green Bay (Brown County) ranged from 78 to 134 days 
(average 109) while Manitowoc (Manitowoc County) ranged from 72 to 133 days (average 102) between 2003 and 2014. [21], In Kewaunee County, there were 120 days of frozen ground during the winter of 2013-2014 [9]. The average number of days with $>2.5 \mathrm{~cm}$ (1 inch) of snow cover ranges from about 70 in the south along the Lake Michigan shoreline to about 90 in western Brown County [22].

The four-county study area includes Brown, Calumet, Kewaunee and Manitowoc counties (Figure 1). Land use in the study area is characterized by a mix of urban development, small rural communities and industries, including manufacturing, dairy (bovine) livestock production and agricultural field crops, but the majority of the study area is $>75 \%$ cultivated land [23]. With the exception of areas near the Fox River and the Bay of Green Bay in Brown County, the region's municipal boundaries are largely based on the U.S. Public Land Survey System, in which Towns $\left(93.2 \mathrm{~km}^{2}\left(36 \mathrm{mi}^{2}\right)\right)$ are the most basic unit of local government in rural areas. Several towns, villages, and cities occur within counties.

The residents and manufacturing industries in the region rely on both ground and surface water [24], while the livestock production industry relies entirely on groundwater. In the four-county study area, only the City of Manitowoc in Manitowoc County and major municipalities near Green Bay in Brown County utilize surface water for municipal supplies. Rural regions making up most of the four-county study area depend on either domestic wells or municipal wells to provide potable water resources [7]. The vast majority of agricultural field crops rely on annual precipitation as their sole source of moisture [25-27]

The dairy industry in the four counties has recorded a 30\% increase in milking cows between 2002 and 2012 (from 131,500 to 172,500) [25-27] and a corresponding increase of 5.2 million kiloliters to 6.53 million kiloliters of animal waste annually (Figure 3). In the study area, 100\% of the animal waste (manure) is land applied. More than half of the waste is stored and applied seasonally (usually in the fall and spring months), however, year to year variations in weather result in some stored manure being land applied to frozen ground. Less than $5 \%$ of the volume is treated with anaerobic digestion prior to land application. The increase in bovine numbers, and associated increase in manure volume applied to the land increases the risk of manure contamination occurring.

Statewide, restrictions on the land application of manure (in both karst and non-karst areas) are based on the USDA NRCS 590 Nutrient Management Standard [28]. This technical standard is referenced in several state laws that govern manure and fertilizer application including ATCP 50 and NR 151.

A statewide survey in 1994 of 538 wells [29] showed positive detections for coliform bacteria in $23.3 \%$ of the state's wells, with $E$. coli in $2.5 \%$ of the wells, and $6.5 \%$ of wells exceeding $10 \mathrm{ppm}$ nitrate-nitrogen. In the region, sediment and pathogen contamination of the shallow aquifer has long been a common occurrence. Concerns regarding coliform bacteria, E. coli, and nitrate in the region's wells became greater during the late 1990 s and early $2000 \mathrm{~s}$, as the number of contaminated wells and the severity of the contamination continued to rise $[13,30]$. WDNR policy denotes any well with any detectable coliform, any type of $E$. coli or any pathogen as contaminated by a pathogenic indicator [30]. Wells over $2.0 \mathrm{ppm}$ nitrate-nitrogen are also considered impacted by human activity, while those over $10 \mathrm{ppm}$ are considered unsafe (above the WNDR heath standard) for sensitive populations (young children, pregnant women) $[13,30]$. 


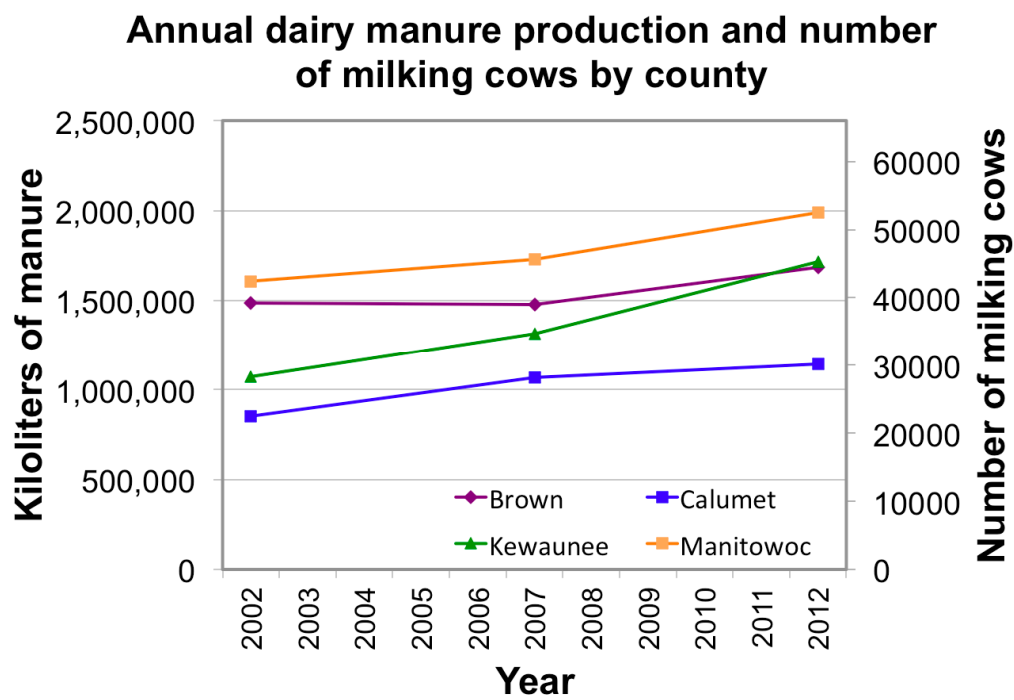

Figure 3. Estimates of annual dairy manure production by county (left axis) and the number of milking cows by county in the four-county study area (right axis). Values show increasing population trends and manure production volumes over time [25-27].

Voluntary well testing programs in two to six townships in Calumet, Brown, Kewaunee, and Manitowoc counties documented between $20 \%$ and $30 \%$ of wells exceed the nitrate-nitrogen standard of $10 \mathrm{ppm}[8,13]$. Targeted testing programs of more than 1000 wells between 2002 and 2005 in Calumet County revealed that $35 \%$ of the samples were positive for coliform bacteria, and $4.6 \%$ were positive for $E$. coli. The testing also showed that $53 \%$ of wells had elevated levels of nitrate-nitrogen (2-10 ppm), with $25 \%$ above the health standard of $10 \mathrm{ppm}$ for nitrate-nitrogen. Altogether, $47 \%$ of the wells tested were considered unsafe for either bacteria or nitrate, with $12 \%$ unsafe for both bacteria and nitrate [13].

In Door County (adjacent to the study area with the same geologic, soil and climate features), a well sampling program (2000 samples) showed that on any given day, over one-third of the tests indicated the presence of coliform bacteria [2].

Each spring, snowmelt and rainfall are typical precursors to clusters of contaminated wells in the area, as documented by The Karst Task Force [13] and shown in Table 1. Weather events in February and March of 2006 resulted in both snowmelt and precipitation runoff carrying manure into shallow karst bedrock features and improperly abandoned wells, leading to coliform and E. coli detections in 78 of the 422 tested wells in the Town of Morrison [13]. Public pressure resulting from this event and previous clusters of contamination led to the formation of the Northeast Wisconsin Karst Task Force (KTF) [13].

Table 1. Example contamination cases $[13,30]$.

\begin{tabular}{ccc}
\hline Incident Location & Date & Impact \\
\hline Town of Morrison, Brown County & February-March, 2006 & 78 wells tested unsafe for coliform bacteria and/or E. coli \\
Town of Franklin, Manitowoc County & 2005 & 10 wells tested unsafe for coliform bacteria; 6 positive for E. coli \\
Town of Luxemburg, Kewaunee County & March, 2004 & A single well contamination by manure that tested positive for \\
& & E. coli resulted in severe illnesses and hospitalizations \\
\hline
\end{tabular}


The objective of this study was to evaluate groundwater quality changes that occurred in a four-county region of northeastern Wisconsin to determine whether or not implementation of recommendations from a regional task force had an impact on groundwater quality in the region. A brief description of the Karst Task Force results and regulatory/policy changes that resulted are presented below.

\section{Results of the 2007 Karst Task Force (KTF)}

\subsection{Purpose and Justification}

The KTF was charged with examining the available scientific data and with making recommendations on how to address the groundwater contamination problem. The Task Force consisted of researchers and experts from five University of Wisconsin institutions, resource managers from county Land and Water Conservation Departments, and the state environmental agencies (Wisconsin Department of Ag Trade and Consumer Protection and Department of Natural Resources (WDNR)), a crop consultant, farmer, a professional manure hauler, a USDA Natural Resources Conservation Service (NRCS) District Conservationist, and a well driller. Outside contributors included hydrogeologists from the Minnesota DNR, the University of Minnesota, and a private engineering consultant.

The Task Force focused on agricultural issues, as the primary land use in the karst area is livestock and cash crop agricultural production, and the trends noted in NASS [25] showed the number of livestock increasing and with a concurrent decrease in available cropland for manure application. Task Force members agreed that because of the aquifer type, overlying soils and land use practices, it would be impossible to prevent every instance of contamination, but that landowners can take significant steps to reduce the potential for animal and human waste, and other materials from entering the groundwater [13]. It also became clear that the physical environment cannot be characterized, understood, or protected by merely locating and managing karst features visible at the surface. Rather, the controlling factor is the underlying fractured carbonate bedrock and the pathways through which surface contaminants may enter the bedrock environment.

This task force created a set of recommendations, of which two counties chose to implement restrictions on the application of animal waste (manure) to reduce the risk of groundwater contamination in 2007. This article represents the first regional analysis of the KTF and subsequent regulatory changes to determine if these regulations impacted the prevalence of wells contaminated with animal waste and the frequency of BWIs. This paper is the first analysis of the impacts of the task force report and the effectiveness of actions taken by local resource managers that have been examined with regard to groundwater quality.

\subsection{Regulatory and Policy Responses to the 2007 KTF Report}

The two counties that implemented regulations varied in their approach. Manitowoc County was the stricter of the two, implementing both year-round and frozen soil restrictions on manure application [31-33] in 2007. Year round restrictions included (1) No application within $30.5 \mathrm{~m}$ of a known karst feature, (2) requiring incorporation (injecting or mixing into the soil) of animal manure 
within $48 \mathrm{~h}$ of application on any site (a) within 30.5-151.5 m of a known karst feature, and (b) any area that drained into a known karst feature. Seasonal (frozen soil) restrictions include no applications of liquid manure on slopes $>6 \%$ when unable to incorporate within $48 \mathrm{~h}$. Solid manure can be applied on slopes between $6 \%$ and $12 \%$ if at least $40 \%$ of the soil surface is covered with crop residue. Manitowoc County does not require pre-approval of application sites, but has created maps of the above restrictions and made them available to livestock farmers, agronomic consultants and the general public. Exemptions are not granted for incorporation or setbacks. Violators may be fined $\$ 500$ (US) plus fees. The county ordinance was voted on by each town in the county, and passed on a popular vote.

Regulations implemented in Brown County in 2007 [34] required the land manger to gain pre-approval for seasonal land application by submitting a winter manure spreading plan (WSP). The focus of the WSP is to prioritize fields from lowest to highest risk, with maps showing karst features provided to farmers and agronomic consultants. There are no mandatory additional incorporation requirements or setbacks from karst features. Manure application rates are pre-approved by the SWCD. Non-mandatory recommendations include limiting manure application to 46,670 L/hectare and $44,834 \mathrm{~kg} /$ hectare and encouraging larger setbacks from wells and karst features. The Brown County ordinance addresses only manure and not other waste applications.

Three other counties (Calumet, Door, Kewaunee) used the 2007 KTF report to begin building the case for additional setbacks and regulations, but did not make changes to their county regulations impacting manure and waste application. State regulations continued to be enforced in all five counties.

Calumet County's LWCD created a focused educational approach — identifying the areas of highest risk of contamination and working one on one with landowners and land managers in these areas to identify and map karst features and encourage better management. This was done on a volunteer basis because there were no revisions made to the ordinances, limiting any enforcement and incentive for landowners to change management practices [35-37].

Door County has also documented BWIs. The county did not make any ordinance changes as a result of the 2007 KTF. County Conservationist William Schuster, however, states that the KTF, by providing a solid scientific consensus, has eliminated debate over many issues and reaffirmed that contamination in the karst aquifer is a regional problem, and not just a county problem [38]. Recent (2014) BWIs have brought the issue to the forefront, and changes to manure and waste application regulations are likely to occur. In 2015, Door County is increasing enforcement of existing county ordinances surrounding manure application, however, these ordinances incorporate state rules by reference and do not include the additional winter restrictions that were adopted by Manitowoc and Brown counties [39]

Kewaunee County has continued to experience a high number of BWIs. While no regulatory changes were made in the years following the $2007 \mathrm{KTF}$, the KTF set the stage for a regional approach. Since the release of the KTF report, Kewaunee's past and current resource managers have focused their efforts on identifying features and implementing a detailed well water testing program to delineate the areas of concern. The county board approved detailed aquifer protection ordinance in 2014 and it passed with an $83 \%$ yes vote when placed on every municipal ballot in the county in April 2015. The ordinance prohibits animal waste application on both frozen/snow covered fields and applications between Jan 1 and April 15 on cropland fields with less than $6.1 \mathrm{~m}$ of soil over bedrock and those that drain to these areas [40]. 
All five counties implemented some aspects of the education recommendations made by the KTF by working with key people, such as for-hire manure applicators and consultants, who cross county lines. The county SWCDs and The University of Wisconsin - Extension partnered to increase outreach and education to three key audiences: (1) Commercial Manure Applicators: Responsible for $>60 \%$ of the manure applied in the target area, educational modules were added to their Level 1 and Level 2 certification program to provide basic and advanced training to manure applicators, (2) Nutrient Management Plan Writers: Task force members communicated recommendations directly to plan writers at their statewide conferences and at local meetings and (3) Farmers: Information and KTF recommendations were included in the farmer training sessions for those farms writing their own Nutrient Management Plans.

\section{Methods}

\subsection{Data Sources and Statistical Analysis}

Three sources of water quality data for domestic water wells were compiled during this study. These included state regulatory agency (Wisconsin Department of Natural Resources-WDNR) records, County health department $(\mathrm{CH})$ records, and various county Land and Water/Soil and Water Conservation District (SWCD) records. Data were compiled from each source for as many years as records existed prior to 2007 (starting in 2002), and for the 2008-2014 timeframe. Data acquired from the sources included the date, well location, whether the color change in the water (BWI) was observed by a trained individual (WNDR, $\mathrm{CH}$ or SWCD staff), and the presence of a strong animal waste odor that would deter bathing or laundry (ODOR). As well testing is often suggested when a neighboring well is contaminated, data requested included either BWI or ODOR in that well or a nearby well along with a positive pathogenic indicator test, and lastly, a lack of either BWI or ODOR, but a nearby well had documented pathogenic indicators, ODOR or BWI. Data were received as Excel spreadsheets, and the data were then imported into SPSS (version 23.0) for statistical analysis. A Chi-Square test was computed to test for any statistically significant association between the treatments (year samples were taken (pre-2007 and post-2007) and frozen ground (presence or absence of frozen ground)) and the variables mentioned above.

WDNR records included staff investigations of homeowner-reported well contamination. Depending on the situation and the time between the initial report and staff visit, these may include records of visual documentation of BWIs, nasal detection of odors, laboratory detections of bacteria or nitrate, or if a specialized bacterial testing was conducted. A well was determined to be impacted by animal waste if trained staff sampled the well, followed WDNR or written CH QA/QC protocols, and one of the following tests produced conclusive results: (1) presence of Rhodococcus corpophilus, (2) presence of E. coli at levels higher than what would be attributable to human waste, and/or (3) presence of bovine Bacteroides, as determined by a Microbial Source Tracking (MST) analysis (post 2006) [41]. Data were summarized by WDNR staff at the authors' request. Reliable records were available from WDNR for the time period 2002-2014 for all counties except Door County; hence, it was excluded from this study. 
The SWCD records from each county included staff investigations of homeowner-reported well contamination. The SWCD staff collaborated with WDNR and/or $\mathrm{CH}$ staff to conduct well water quality sampling. SWCD records closely paralleled the records of WDNR. WDNR records were provided to SWCD staff, who then compared them to their records and information they had on file from $\mathrm{CH}$ to complete missing data (such as visual verification of BWIs) or provide well testing results. Thoroughness of data tracking of reported well contamination varied between counties, with some having very complete records and others having no formalized tracking system [42-48].

The $\mathrm{CH}$ records included visual observations, along with E. coli, and Rhodococcus coprophilus test results. Counties with complete records were included in the dataset, either by the SWCD or by providing a copy of the WDNR data to the $\mathrm{CH}$. Data from $\mathrm{CH}$ where no third party verification of BWI or odor existed for an incident, (such as where the well owner collected their own sample, or where it is unknown whether WDNR or CH QA/QC protocols were followed), were excluded from the dataset.

A total of 124 data points were included in the dataset. Sixty-two data points were from the 2002-2006 timeframe and 63 were from the 2008-2014 timeframe. Data from 2007 were excluded because Brown and Manitowoc Counties implemented their regulations during 2007. Twenty-nine of the data points were from Brown County, 12 were from Calumet, 22 were from Kewaunee, and 61 were from Manitowoc County. Multiple instances of contamination were documented in some wells during the studied time period. Multiple events of contamination that occurred within a 14-day period were counted as one contamination. If contamination occurred and the water clarity returned to normal or all pathogenic indicator tests were negative within 14 days and then re-occurred after the initial 14 day period, it was treated as a second instance.

Frozen ground has been identified as a critical factor in BWIs and well water contamination [49,50]. When the ground is frozen, snowmelt and/or precipitation infiltrate more slowly, as some of the pores between soil particles that normally allow for infiltration are filled with frozen water. This decrease in infiltration results in an increase in the volume of water leaving via surface flow. In some years, "concrete frost" or "dense frost" has developed, where a very high percentage of soil pores are filled with ice. This results in a much lower infiltration rate, higher runoff volumes, and has been tied to spikes in well water contamination [49].

For this study, the presence or absence of frozen ground was determined by using the National Oceanic and Atmospheric Administration's (NOAA) Cooperative Observer Database (COD) hosted by UW Madison [21]. A central location was chosen in each county, and for each well contamination event where a month and date of contamination was available, the COD data for that date was accessed. For the purposes of the data analysis, a central location for each county was selected to determine the presence or absence of frozen ground. A central location was selected to avoid the climate mitigating affects of Lake Michigan on the data analysis.

\subsection{Data Limitations}

The data presented in this article represent the most complete data available in the study area. However, the authors recognize several limitations to the dataset. Because the sampling of wells is triggered by an event and well user observations, not all instances of contamination will be documented. Pathogens or other microbial contamination can be present in water with no visual or 
other indication of problems that would trigger sampling. Illnesses caused by pathogens in well water may be misinterpreted as seasonal gastrointestinal illnesses or food poisoning by the well owner, and not necessarily connected to a well contamination problem. Asymptomatic illness and locally acquired immunity are further limitations in the context of illness as an indicator of water quality. All of our data providers $[30,37,40,44,48,51-53]$ noted that some well owners are hesitant to report problems to avoid disrupting neighbor relations, or because of the additional expense of replacing a well or adding a treatment system. By requiring a third party verification of odor or BWI issues, and only including well samples where trained individuals following QA/QC protocols and the same analysis methods were used, our data represent the most reliable instances of positive well contamination indicators. Cow numbers and, as seen in Figure 3, did not hold steady, but increased during the entire study period [25-27].

The majority of human waste in rural areas of Wisconsin is discharged to septic systems with drain fields designed to allow for infiltration of liquids on a continual basis. While some instances of human pathogens in groundwater have been documented in the region (see [7] for details), analysis of human waste is beyond the scope of this paper, and septic system design and installation practices are not likely to have changed significantly during the study period.

The well water quality data gathered in the region are limited by the fact that there is not a scheduled or randomized testing program in place to document BWIs, ODORS or pathogenic indicators in rural wells. While it is clear that such contamination events occur, the true frequency and severity of these events remain unknown.

In addition, an ongoing WDNR well replacement subsidy program [7] and decisions by individual homeowners not participating in the subsidy program have resulted in numerous wells to be replaced in the karst region of the state. While this is a potential confounding factor, it is unlikely to be significant for the observed water quality changes because many of these wells were replaced in the two counties that did not adopt regulatory changes restricting winter spreading. If well replacement was the first-order cause of water quality improvement, we expect that this response should be seen in all four counties analyzed.

The $2007 \mathrm{KTF}$ report focused on reducing BWIs in 5 counties. A combination of factors led us to exclude Door County from the analysis. Most importantly, complete datasets for 2002-2014 were not available from WDNR and SWCD for Door County. The WDNR was also unable to provide a complete dataset for this county as a result of staffing issues [54]. The SWCD stated [38] that they have not historically tracked BWIs and contamination, as it is considered to be a common occurrence. They noted that they are actively working with the Door County Health Department and landowners to address the problem.

\section{Results}

Our results revealed that no statistically significant changes occurred in counties that only had education and training for manure application in a karst setting. However, in all scenarios tested, at least one statistically significant association occurred with counties that implemented regulatory changes as a result of the 2007 KTF report (Brown County, Manitowoc County, or both). Implementing seasonal restrictions on waste application has had a positive impact on ground water 
quality in the four counties in our study by reducing bacterial contamination from 35 documented cases (pre-2007) to 15 (post-2007) in the four county area, a fifty-seven percent decrease. Twenty-eight cases were documented in the two counties (pre-2007) that implemented regulations before implementation and eight after regulations were implemented (post 2007). The same number of cases was documented in the two non-regulated counties ( 7 total) in the pre and post 2007 timeframes. For BWIs, there was a $38 \%$ increase (from 5 to 8 ) in the counties with regulations, but a $70 \%$ increase (from 10 to 17) in the counties without. Since almost half of the data points originated in Manitowoc County due to a more aggressive testing program implemented by the County Health Department, the increased numbers are not unexpected.

\subsection{Restrictions on Frozen Ground Spreading}

The statistical analysis showed that the implementation of restrictions on winter (frozen ground) spreading of animal waste has likely had an impact on the documented instances of well contamination. In almost every variable examined, at least one of the regulated counties (Brown or Manitowoc) showed a statistically significant difference when the pre-regulation period (2002-2006) was compared to the post regulation period (2008-2014).

For BWIs, the Chi-Square analysis determined significance at the 0.01 level. The analysis showed Manitowoc County was statistically significant $(p=0.003)$, but not significant for the other three counties (Brown $(p=0.204)$, Calumet $(p=0.377)$ and Kewaunee $(p=1.00))$. For a confirmed ODOR, significance was at the 0.01 level. The data were significant for Manitowoc County $(p=0.003)$, with non-significance for the other three counties (Brown $(p=0.204)$, Calumet $(p=0.190)$ and Kewaunee $(p=0.35))$.

Where BWI and/or ODOR was present, and a pathogenic indicator test produced conclusive results with the presence of Rhodococcus coprophilus, presence of E. coli at levels higher than what would be attributable to human waste, and/or presence of bovine Bacteroides, as determined by a Microbial Source Tracking (MST) analysis, significance was at the 0.05 level. The data were statistically significant for Brown County $(p=0.017)$, with non-significance for the other three counties (Manitowoc County ( $p=0.06)$, Calumet County $(p=0.855)$ and Kewaunee County $(p=0.448)$ ).

In cases where the well owner did not have a BWI or ODOR, but the well was sampled because a neighboring well did, significance was at the 0.01 level. Both Brown $(p=0.000)$ and Manitowoc counties $(p=0.020)$ were significant, but the other two counties were not significant (Calumet $(p=0.345)$ and Kewaunee ( $p=$ number not recorded as there was only one level of this variable for this county and is hence a constant)). In cases where the well had a positive pathogenic indicator test with or without BWI or ODOR, significance occurs at the 0.01 level. Significant for Brown County $(p=0.000)$, but not significant for the other three counties (Calumet $(p=0.554)$, Kewaunee $(p=0.448)$ and Manitowoc $(p=0.945))$.

\subsection{Presence or Absence of Frozen Soil}

The statistical analysis shows that the presence or absence of incidents involving spreading of animal waste on frozen ground likely had an impact on the documented instances of well 
contamination. In almost every variable examined, at least one of the regulated counties (Brown, Manitowoc) showed a statistically significant difference compared to the non-regulated counties.

For BWIs, significance occurs at the 0.01 level. Results were significant for Manitowoc County $(p=0.001)$, but not significant for the other three counties (Brown $(p=0.842)$, Calumet $(p=0.490)$ and Kewaunee $(p=0.211)$ ). For confirmed strong manure odor (ODOR), Significance occurred at the 0.01 level. The results were significant for Manitowoc County $(p=0.001)$, but not significant for the other three counties (Brown $(p=0.842)$, Calumet $(p=0.301)$ and Kewaunee $(p=0.061)$ ).

In cases with a positive pathogenic indicator test and either BWI or ODOR in the well or a neighboring well, the Chi-Square test showed a statistically significant difference $(p=<0.05)$. Values for each county were: Brown $(p=0.045)$, Calumet $(p=0.490)$, Kewaunee $(p=0.377)$ and Manitowoc $(p=0.13)$. In cases with a positive pathogenic indicator test and BWI or ODOR, Significance occurs at the 0.05 level. The results were significant for Manitowoc County $(p=0.015)$, but not significant for the other three counties (Brown $(p=0.152)$, Calumet $(p=0.325)$ and Kewaunee $(p=0.371)$ ).

In cases where the well did not have BWI or ODOR but was sampled because of neighbor's well did, significance occurs at the 0.01 level. The results were significant for Brown County $(p=0.000)$, but not significant for the other three counties ((Calumet $(p=0.490)$, Kewaunee and Manitowoc counties ( $p=$ number not recorded as there was only one level of this variable for these counties and is hence a constant)). In cases where the well tested positive for a pathogenic indicators, regardless of other factors, significance occurred at the 0.01 level. The results were significant for Brown County $(p=0.000)$ and Manitowoc County $(p=0.005)$, but not significant for the other two counties (Calumet $(p=0.175)$, Kewaunee $(p=0.371))$.

\section{Discussion}

The objective of this study was to evaluate groundwater quality changes that occurred in a four-county region of northeastern Wisconsin to determine whether or not implementation of recommendations from a regional task force had an impact on groundwater quality in the region. By comparing the pre-regulation and post-regulation statistics, the counties that implemented WSPs had a statistically significant impact in one or both regulated counties on reducing the number of BWIs, ODORS, and pathogenic indicator bacteria in groundwater. This study also verifies that the presence of frozen ground and implementing the WPSs reduced BWIs, ODORS and pathogenic indicator bacteria in groundwater.

The data showed an overall decrease in the number of pathogenic indicator bacteria in the counties that implemented regulations, with 28 recorded incidents in the pre-2007 period and 8 in the post 2007 period. Pathogenic indicator bacteria remained constant (7) in the other two counties that did not implement regulations. BWIs showed a lower rate of increase $(38 \%)$ in regulated counties ( 5 pre $/ 8$ post) versus $70 \%$ in non-regulated counties (10 pre/17 post). The increase in manure volume (Figure 3) applied in the target area may or may not be a factor, and was beyond the scope of this study.

The average snowfall totals, number of days with snow cover, and number of days with frozen ground were higher during the second half of the study due to decadal-scale climate anomalies. [20,55]; Manitowoc recorded an average of 93 days frozen ground in the first part of the study and 107 in the second. Only one year of frozen ground data prior to 2007 was available for Green Bay. [21]. 
However, it is unlikely that these variables had a strong influence on the observed trends for two principal reasons. First, increased snowfall would be expected to produce increased spring runoff and greater groundwater quality impacts during the 2008-2014 period, which was not observed. Second, and more importantly, these inter-annual climatological variations would not be expected to impact only Brown and Manitowoc counties, rather, if significant they should have impacted all four analyzed counties. What is more likely important for limiting spring infiltration is the percentage of ice-filled soil pores, which is a complex function of freeze-thaw cycles and winter rain precipitation events [49]. Therefore, we feel that these potential confounding factors were not likely of first-order importance in the observed changes in water quality.

\section{Future Trends}

Within the past year, Kewaunee County passed a winter spreading ordinance that is more restrictive than either the Brown or Manitowoc ordinances [40]. Starting in 2015, this regulation prohibits the land application of animal waste during the frozen ground months and extends into the thawed period (15 April). Future study will be needed to determine the impact of this regulation on well water.

On a statewide level, the proposed revisions to the USDA NRCS 590 Nutrient Management Standard [56-58] includes the designation of "Silurian Dolomite" soils as "areas where Silurian dolomite bedrock is present within $1.52 \mathrm{~m}$ (60 inches) of the surface." It is clear that the $2007 \mathrm{KTF}$ report is reflected in the current draft of the WI NRCS 590 practice standard including: the immediate (subsurface) incorporation of manure within $24 \mathrm{~h}$ in areas known to deliver surface water runoff to direct conduits to groundwater and no winter application of liquid manure in February and March when soils are frozen or snow covered [57].

\section{Conclusions}

The combination of the geology of northeastern Wisconsin and the seasonal spreading of animal waste (manure) on frozen soil are contributing factors to the detection of pathogen indicator bacteria in the aquifer and Brown Water Incidents (BWIs). The implementation of seasonal winter manure spreading restrictions on these sensitive areas did not eliminate the contamination, but did significantly reduce the risk of both pathogen contamination and BWIs, resulting in improved aquifer water quality.

\section{Acknowledgments}

We are very grateful to the many individuals cited in this article that provided water quality data and other information, without which this study could not have been completed. Steve Buan (NOAA) and Rick Wayne (UW Madison) helped with finding some of the climatological data used in the study. Dave Mechenich (UW Stevens Point Center for Watershed Science and Education) and Sarah Congdon (UW Extension Environmental Resources Center) provided drafting and graphics assistance. Jenna Klink helped review some of the statistical analysis results. We are also grateful to three anonymous reviewers, whose comments and suggestions greatly enhanced this paper. 


\section{Author Contributions}

Kevin Erb was responsible for the data collection, and worked with WDNR, CH and SWCD staff in four counties to gather the data and coordinating the writing of the paper. Eric Ronk's contribution includes early data gathering and summarization of contamination issues in the region (prior to his current position) researching and meeting with Calumet County LWCD staff to draft and update part of the results, as well as the data on the trends in the dairy industry in the region. Vikram Koundinya performed the statistical analyses. John Luczaj provided information on geological and climatological data, and assisted in the development of the project, as well as edited the figures and tables.

\section{Conflicts of Interest}

The authors declare no conflict of interest.

\section{References}

1. Ford, D.; Williams, P. Karst Hydrogeology and Geomorphology, 2nd ed.; John Wiley \& Sons Ltd.: West Sussex, UK, 2007; pp. 1-562.

2. Coxon, C. Chapter 5, Agriculture and Karst. In Karst Management, 1st ed.; van Beynen, P.E., Ed.; Springer: New York, NY, USA, 2011; pp. 103-138

3. Guo, F.; Yuan, D.; Qin, Z. Groundwater Contamination in Karst Areas of Southwestern China and Recommended Countermeasures. Acta Carsologica 2015, 32, 389-399.

4. Worthington, S.R.H.; Smart, C.C.; Ruland, W.W. Assessment of Groundwater Velocities to the Municipal Wells at Walkerton. In Ground and Water: Theory to Practice; Proceedings of the 55th Canadian Geotechnical and 3rd Joint IAH-CNC and CGS Groundwater Specialty Conferences, Stolle, D., Piggott, A.R., Crowder, J.J., Eds.; Niagara Falls, ON, USA, 20-23 October 2002; pp. 1081-1086.

5. Celico, F.; Musilli, I.; Naclerio, G. The impacts of pasture- and manure-spreading on microbial groundwater quality in carbonate aquifers. Environ. Geol. 2004, 46, 233-236. doi:10.1007/s00254-004-0987-2.

6. Hrudey, S.E.; Payment, P.; Huck, P.M.; Gillham, R.W.; Hruday, E.J. A fatal waterborne disease epidemic in Walkerton, Ontario: Comparison with other waterborne outbreaks in the developed world. Water Sci. Technol. 2003, 47, 7-14.

7. Luczaj, J.A.; Masarik, K. Groundwater Quantity and Quality Issues in a Water-Rich Region: Examples from Wisconsin, USA. Resources 2015, 4, 323-357.

8. Center for Watershed Science and Education (CWSE) WI Well Water Viewer. University of Wisconsin-Stevens Point. Available online: http:/www.uwsp.edu/cnr-ap/watershed/Pages/ WellWaterViewer.aspx (accessed on 29 June 2015).

9. Bonness, D.; Masarik, K. Investigating Intra-annual Variability of Well Water Quality in Lincoln Township; Final Report; June 2014; pp. 1-42. Available online: http://www.uwsp.edu/cnrap/watershed/Documents/Lincoln_FinalReport.pdf (accessed on 2 July 2015).

10. Bauer, A.C.; Wingert, S.; Fermanich, K.J.; Zorn, M.E. Well water in karst regions of northeastern Wisconsin contains estrogenic factors, nitrate, and bacteria. Water Environ. Res. 2013, 85, 318-326. 
11. Borchardt, M.A.; Bradbury, K.R.; Alexander, E.C., Jr.; Kolberg, R.J.; Alexander, S.C.; Archer, J.R.; Braatz, L.A.; Forest, B.M.; Green, J.A.; Spencer, S.K. Norovirus outbreak caused by a new septic system in a dolomite aquifer. Ground Water 2011, 49, 85-97.

12. Borchardt, M.A.; Bertz, P.D.; Spencer, S.K.; Battigelli, D.A. Incidence of enteric viruses in groundwater from household wells in Wisconsin. Appl. Environ. Microbiol. 2003, 69, 1172-1180.

13. Erb, K.R.; Stieglitz, R. Final Report of the Northeast Wisconsin Karst Task Force; University of Wisconsin-Extension: Madison, WI, USA, 2007; pp. 1-46.

14. Czymmek, K.; Geohring, L.; Lendrum, J.; Wright, P.; Albrecht, G.; Brower, B.; Ketterings, Q. Manure Management Guidelines for Limestone Bedrock/Karst Areas of Genesee County, New York: Practices for Risk Reduction; Animal Science Publication Series No. 240; Cornell University: Ithaca, NY, USA, 2011; pp. 1-9. Available online: http://nmsp.cals.cornell.edu/publications/files/ Karst_2_15_2011.pdf(accessed on 8 August 2015).

15. Ronk, E.; Erb, K. A Preliminary Analysis of 300 Manure Incidents in Wisconsin. In Proceedings of the 2010 Wisconsin Crop Management Conference, Madison, WI, USA, 12-14 January 2010.

16. Gupta, S.; Munyankusi, E.; Moncrief, J.; Zvomuya, F.; Hanewall, M. Tillage and Manure Application Effects on Mineral Nitrogen Leaching from Seasonally Frozen Soils. J. Environ. Qual. 2004, 33, 1238-1246.

17. Luczaj, J.A. Geology of the Niagara escarpment in Wisconsin. Geosci. Wis. 2013, 22, 1-34. Available online: http://wgnhs.uwex.edu/pubs/gs22a01/ (accessed on 2 July 2015).

18. Mudrey, M.G., Jr.; Brown, B.A.; Greenberg, J.K. Bedrock Geologic Map of Wisconsin; University of Wisconsin-Extension, Geological and Natural History Survey: Madison, WI, USA, 1982; scale $=1: 1,000,000$.

19. NOAA - National Weather Service, Index of Climate Images for Wisconsin. Available online: http://www.crh.noaa.gov/images/mkx/climate/ (accessed on 2 July 2015).

20. Wisconsin State Climatology Office (WSCO). Statewide Wisconsin Climate Data. Available online: http://www.aos.wisc.edu/ sco/clim-history/state/ (accessed on 2 July 2015).

21. University of Wisconsin-Extension, Wisconsin Cooperative Observer Database, Wisconsin State Climatology Office (WSCO). Available online: http://agwx.soils.wisc.edu/uwex_agwx/ weather/hyd (accessed on 7 July 2015).

22. Wisconsin State Climatology Office (WSCO). Wisconsin Winter Climate. Available online: http://www.aos.wisc.edu/ sco/seasons/winter.html\#Snow (accessed on 2 July 2015).

23. Department of Agriculture, Trade and Consumer Protection (DATCP). Agricultural Chemicals in Wisconsin Groundwater (April 2008). Available online: http://datcp.wi.gov/uploads/ Environment/pdf/ARMPub180.pdf (accessed on 20 August 2015).

24. Krohelski, J.T. Hydrogeology and Ground-Water Use and Quality, Brown County, Wisconsin; Wisconsin Geological and Natural History Survey: Madison, WI, USA, 1986; Volume 57, pp. 1-42.

25. United States Department of Agriculture, National Ag Statistics Service (UDSA, NASS). 2002 Census of Agriculture. Available online: http://www.agcensus.usda.gov/Publications/2002/ (accessed on 8 July 2015).

26. USDA, NASS. 2007 Census of Agriculture. Available online: http:/www.agcensus.usda.gov/ Publications/2007/ (accessed on 8 July 2015). 
27. USDA, NASS. 2012 Census of Agriculture. Available online: http://www.agcensus.usda.gov/ Publications/2012/ (accessed on 8 July 2015).

28. United States Department of Agriculture, Natural Resources Conservation Service. March 2005 Wisconsin NRCS 590 Standard. 4 July 2015. Available online: http://efotg.sc.egov.usda.gov/references/public/WI/590.pdf (accessed on 8 July 2015).

29. Warzecha C.; Gerhardt, R.; Kluender, S. Wisconsin Private Well Water Quality Survey; NGWIC Call Number GB1025.W6.W45; Wisconsin Department of Natural Resources: Madison, WI, USA, 2015.

30. Heinen, L. Drinking Water and Ground Water Specialist, Wisconsin Department of Natural Resources. Personal Communication, 7 April 2015.

31. Smith, T. Resource Conservationist, Manitowoc Soil and Water Conservation Department, Manitowoc, WI, USA. Personal Communication, 7 April 2015.

32. Riesterer, B. Resource Conservationist, Manitowoc Soil and Water Conservation Department, Manitowoc, WI, USA. Personal Communication, 7 April 2015.

33. Manitowoc County, Wisconsin. Ordinances, Chapter 19, Animal Waste Management. Available online: http://www.manitowoccounty.com/Upload/8/Chapter\%2019\%20-\%202011-0118H.pdf (accessed on 5 May 2015).

34. Brown County, Wisconsin. Ordinances, Chapter 26, Animal Waste Management. Available online: http://www.co.brown.wi.us/i_brown/d/county_clerk/2013_web/chap026-updated_6-24-13.pdf? $\mathrm{t}=1373902597$ (accessed on 5 May 2015).

35. Kleiber, A. Land Resource Specialist, Calumet County Land and Water Conservation Department, Chilton, WI, USA. Well water incidents. Personal Communication, 4 April 2015.

36. Reali, A. County Conservationist, Calumet County Land and Water Conservation Department, Chilton, WI, USA. Well water incidents. Personal Communication, 8 April 2015.

37. Santry, D. Water Resource Specialist, Calumet County Land and Water Conservation Department, Chilton, WI, USA. Well water incidents. Personal Communication, 8 April 2015.

38. Schuster, W. County Conservationist, Door County Soil and Water Conservation Department, Sturgeon Bay, WI, USA. Well water incidents. Personal Communication, 7 April 2015

39. Schuster, W. County Conservationist, Door County Soil and Water Conservation Department, Sturgeon Bay, WI, USA. Brown water incidents. Personal Communication, 27 June 2015

40. Bonness, D. County Conservationist, Kewaunee County, Wisconsin Land and Water Conservation Department, Luxemburg, WI, USA. Personal Communication, 7 April 2015.

41. Layton, A.; McKay, L.; Williams, D.; Garrett, V.; Gentry, R.; Sayler, G. Development of Bacteroides 16S rRNA Gene TaqMan-Based Real-Time PCR Assays for Estimation of Total, Human, and Bovine Fecal Pollution in Water. Appl. Environ. Microbiol. 2006, 72, 4214-4224, doi:10.1128/AEM.01036-05.

42. Wergin, A. RN BSN, Health Officer, Manitowoc County Health Department, Manitowoc, WI, USA. Karst Data. Personal Communication, 17 June 2015.

43. Kinnard, C. Registered Nurse, Public Health Director, Kewaunee County Health Department, Kewaunee, WI, USA. Karst Paper. Personal Communication, 18 May 2015.

44. Halverson, J. County Conservationist, Manitowoc County, Wisconsin Soil and Water Conservation Department, Manitowoc, WI, USA. Research Paper. Personal Communication, 5 May 2015. 
45. Bonness, D. County Conservationist, Kewaunee County, Wisconsin Land and Water Conservation Department, Luxemburg, WI, USA. Personal Communication, 4 April 2015.

46. Jolly, J. County Conservationist, Brown County Land and Water Conservation Department, Green Bay, WI, USA Personal Communication, 3 April 2015.

47. Santry, D. Water Resource Specialist, Calumet County Land and Water Conservation Department, Chilton, WI, USA. Karst Data Request. Personal Communication, 14 April 2015.

48. Gollman, R. Environmental Lab Manager, Brown County (WI) Health Department, Green Bay, WI, USA. Personal Communication, 13 May 2015.

49. Komiskey, M.J.; Stuntebeck, T.D.; Frame, D.R.; Madison, F.W. Nutrients and sediment in frozen-ground runoff from no-till fields receiving liquid-dairy and solid-beef manures. J. Soil Water Conserv. 2011, 66, 303-312, doi:10.2489/jswc.66.5.303.

50. State of Wisconsin. Final Report of the Manure Management Task Force; Wisconsin Department of Ag, Trade and Consumer Protection: Madison, WI, USA, 10 March 2006.

51. Wergin, A. RN BSN, Health Officer, Manitowoc County Health Department, Manitowoc, WI, USA. Karst Data. Personal Communication, 17 June 2015.

52. Jolly, J. County Conservationist, Brown County Land and Water Conservation Department, Green Bay, WI, USA. Personal Communication, 3 April 2015.

53. Kinnard, C. Registered Nurse, Public Health Director, Kewaunee County Health Department, Kewaunee, WI, USA. Maps for paper. Personal Communication, 18 May 2015.

54. Merry, J. Water Supply Specialist, Hydrogeologist, WDNR, Green Bay, WI, USA. Current spreadsheet data. Personal Communication, 8 June 2015.

55. Wisconsin State Climatology Office (WSCO). Green Bay Climate-Number of Days of 1 Inch or More Now Cover Per Snow Season: Green Bay Airport (1949/1950-2013/2014 season). Available online: http://www.aos.wisc.edu/ sco/clim-history/stations/grb/GRB-AP-D-snwcv.gif (accessed on 2 July 2015).

56. USDA, NRCS. Draft March 2015 Wisconsin NRCS 590 Standard. Available online: http://socwisconsin.org/wp-content/uploads/2015/03/Draft590Standard_BroadReview.pdf (accessed on 15 April 2015).

57. USDA, NRCS. Draft March 2015 Wisconsin NRCS 590 Tech Note 1. Available online: http://socwisconsin.org/wp-content/uploads/2015/03/590TechNote_BroadReview1.pdf (accessed on 15 April 2015).

58. Murphy, P. State Resource Conservationist, United States Department of Agriculture Natural Resources Conservation Service, Madison, WI, USA. Personal Communication, 13 April 2015.

(C) 2015 by the authors; licensee MDPI, Basel, Switzerland. This article is an open access article distributed under the terms and conditions of the Creative Commons Attribution license (http://creativecommons.org/licenses/by/4.0/). 